\title{
Short-term surviving sirenomelia neonate followed by a complex mesodermal malformation in a sibling
}

\author{
Giuliano Rigon, ${ }^{1}$ Cristina Vallone, ${ }^{1}$ Evelina Silvestri, ${ }^{2}$ Fabrizio Signore ${ }^{1}$
}

${ }^{1}$ Department of Obstetrics and Gynaecology, San Camillo Forlanini Hospitals, Rome, Italy ${ }^{2}$ Department of Anatomical Pathology, San Camillo Forlanini Hospitals, Rome, Italy

\section{Correspondence to}

Dr Fabrizio Signore, fsignore@ scamilloforlanini.rm.it

\section{DESCRIPTION}

A surviving sirenomelia with renal agenesis was followed by a caudal mesodermal malformation in a subsequent pregnancy.

A 29-year-old prediabetic overweight woman was diagnosed with fetal sirenomelia after an MRI study following an inconclusive ultrasound at the 28th week of pregnancy. Caesarean section was performed for fetal distress at the 37 th week gestation. The neonate had a cardiac arrest after $32 \mathrm{~h}$. The final diagnosis was sirenomelia with renal agenesis and other midline defects (figure 1). The patient got pregnant again 2 years later. Sonographic evaluation at the 19th week of pregnancy showed anhydramnios possibly due to renal agenesis, and abortion was induced at the 19th week of gestation (figure 2). The final diagnosis was complex mesodermal malformation.

Fetal and maternal karyotypes were normal. Toxicology and molecular probes for maternal coagulation Factors II and V, respectively (FII, FV) and 5,10-methylenetetrahydrofolate reductase genes were normal.
The incidence of sirenomelia is $1 / 60000$ to 70000 pregnancies. ${ }^{1}$ Chromosomal abnormalities are rare. An association with maternal diabetes and mesodermal anomalies has been observed. ${ }^{2}$

Evidence of involvement of the HLXB9 gene in familiar sacral agenesis suggests a possible association. Midline defects and sirenomelia can be induced in the rat by drug toxicity. ${ }^{3}$ Sonographic diagnoses in the first trimester are rare; if anhydramnios does not allow one to detect parallel femoral bones, MRI is the investigation of choice as it is less affected by anhydramnios than sonography.

Sirenomelia can be associated with intrauterine growth retardation, as well as renal dyplasia, a single umbilical artery, abdominal and tracheal-oesophageal defects, neural tube and heart malformations. Only six survivals have been reported. Pulmonary dysplasia due to renal agenesis is the main cause of death. Survival to term with renal agenesis has not yet been reported.
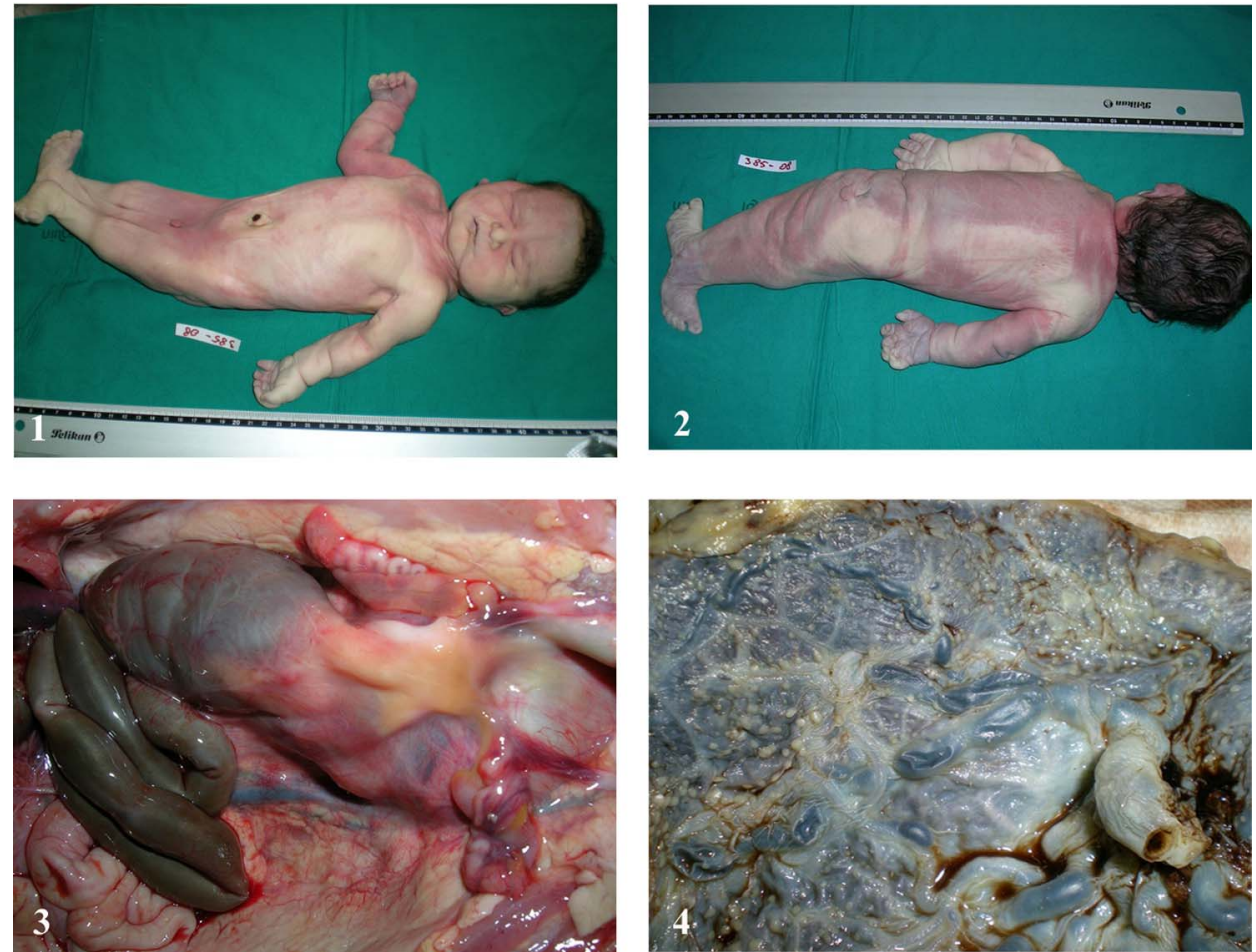

Figure 1 Panels 1 and 2: Sirenomelia front and back views. Panel 3: Autopsy shows double volvulus and rectal atresia. Panel 4: Amnion nodosum. 

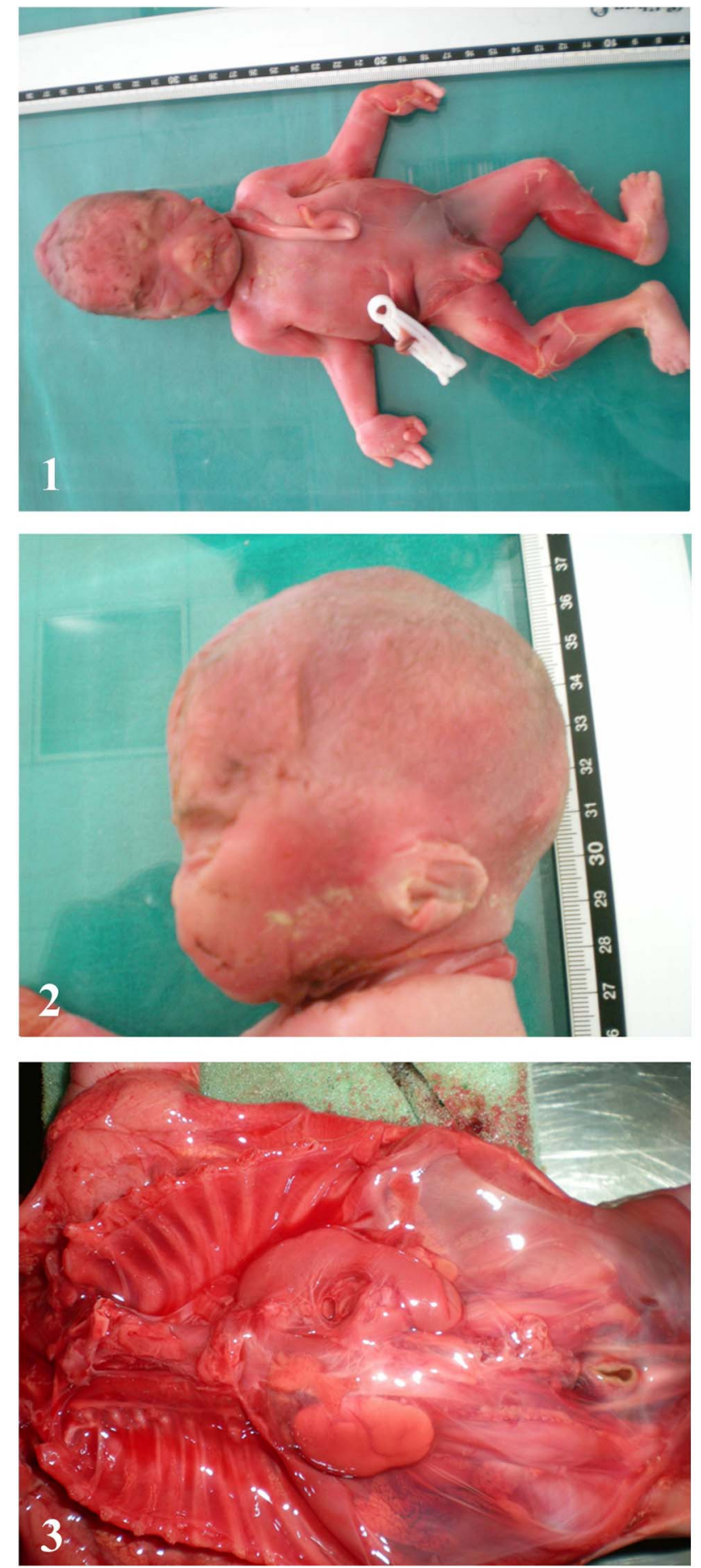

Figure 2 Panels 1 and 2: Fetus front and side views. Panel 3: Autopsy shows renal agenesis.

\section{Learning points}

- Neonatal survival of sirenomelia patients is possible even if renal agenesis is diagnosed or suspected in utero. A final diagnosis and prognosis are only tentative and should be deferred to the neonatal period.

- Obesity and low glucose tolerance are significant risk factors in the genesis of the mesodermal malformation complex.

- Complex mesodermal malformations can exceptionally recur in subsequent pregnancies.

Competing interests None.

Patient consent Obtained.

Provenance and peer review Not commissioned; externally peer reviewed.

\section{REFERENCES}

1 Sikandar R, Munim S. Sirenomelia, the Mermaid syndrome: case report and a brief review of literature. J Pak Med Assoc 2009;59:721-3.

2 Orioli IM, Mastroiacovo P, López-Camelo JS, et al. Clusters of sirenomelia in South America. Birth Defects Res A Clin Mol Teratol 2009;85:112-18.

3 Ross AJ, Ruiz-Perez V, Wang Y, et al. A homeobox gene, HLXB9, is the major locus for dominantly inherited sacral agenesis. Nat Genet 1998;20:358-61. 
Copyright 2013 BMJ Publishing Group. All rights reserved. For permission to reuse any of this content visit http://group.bmj.com/group/rights-licensing/permissions.

BMJ Case Report Fellows may re-use this article for personal use and teaching without any further permission.

Become a Fellow of BMJ Case Reports today and you can:

- Submit as many cases as you like

- Enjoy fast sympathetic peer review and rapid publication of accepted articles

- Access all the published articles

- Re-use any of the published material for personal use and teaching without further permission

For information on Institutional Fellowships contact consortiasales@bmjgroup.com

Visit casereports.bmj.com for more articles like this and to become a Fellow 